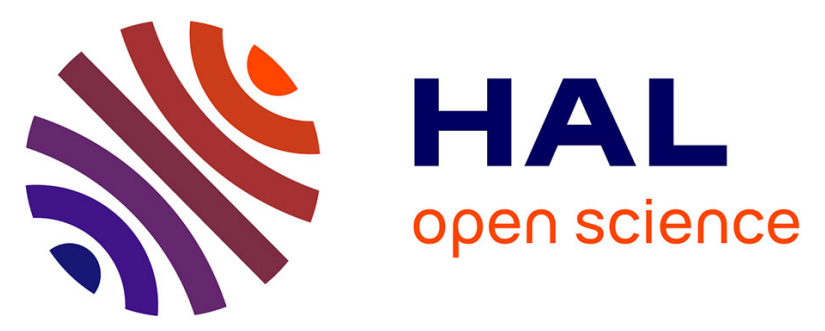

\title{
ABSOLUTE MEASUREMENTS OF THE I2(X) HIGH VIBRATIONAL LEVELS IN THE OXYGEN-IODINE REACTION
}

\author{
B. Barnault, A. Bouvier, D. Pigache, R. Bacis
}

\section{- To cite this version:}

B. Barnault, A. Bouvier, D. Pigache, R. Bacis. ABSOLUTE MEASUREMENTS OF THE I2(X) HIGH VIBRATIONAL LEVELS IN THE OXYGEN-IODINE REACTION. Journal de Physique IV Proceedings, 1991, 01 (C7), pp.C7-647-C7-650. 10.1051/jp4:19917173 . jpa-00250851

\section{HAL Id: jpa-00250851 https://hal.science/jpa-00250851}

Submitted on 1 Jan 1991

HAL is a multi-disciplinary open access archive for the deposit and dissemination of scientific research documents, whether they are published or not. The documents may come from teaching and research institutions in France or abroad, or from public or private research centers.
L'archive ouverte pluridisciplinaire HAL, est destinée au dépôt et à la diffusion de documents scientifiques de niveau recherche, publiés ou non, émanant des établissements d'enseignement et de recherche français ou étrangers, des laboratoires publics ou privés. 


\title{
ABSOLUTE MEASUREMENTS OF THE $I_{2}(X)$ HIGH VIBRATIONAL LEVELS IN THE OXYGEN-IODINE REACTION
}

\author{
B. BARNAULT, A.J. BOUVIER*, D. PIGACHE and R. BACIS*
}

Office National d'Etudes et de Recherches Aérospatiales, BP. 72, F-92322 Châtillon cedex, France *Laboratoire de Spectroscopie Ionique et Moléculaire, Université Lyon I, 43 boulevard du 11 novembre 1918, F-69622 Villeurbanne, France

\begin{abstract}
The dissociation with of $\mathrm{I}_{2}$ by $\mathrm{O}_{2}\left({ }^{1} \Delta \mathrm{g}\right)$ in a Chemical 0xygen Iodine Laser (COIL) cannot occur a single collision. A two-step model where the excited intermediate species is identified with the vibrational states of $I_{2} \times\left(0_{g}^{+}\right)$, with $V$ between 30 and 43 , has been proposed. The existence of these species has already been checked by using laser fluorescence excitation spectroscopy. The aim of this work is to perform absolute measurements of the iodine vibrational levels populations along the reaction zone in order to have a better understanding of the dissociation mechanism.
\end{abstract}

\section{1 - Introduction}

The dissociation of $\mathrm{I}_{2}$ by $\mathrm{O}_{2}\left({ }^{1} \Delta \mathrm{g}\right)$ in a Chemical oxygen Iodine Laser (COIL) cannot occur with a single collision because the energy of $0_{2}\left({ }^{1} \Delta g\right)$ is far less than the dissociation energy of iodine (figure 1).

A two-step dissociation process where the excited intermediate species are supposed to be the vibrational states of $\mathrm{I}_{2} \times\left(0_{\mathrm{g}}^{+}\right)$has been proposed by several groups $(1,2,3)$. David and coworkers proposed a model in agreement with this hypothesis ${ }^{(3)}$. It is consistent with Heidner's model in which the intermediate species $\mathrm{I}_{2}^{*}$ is not identified(4).

According to this model, the dissociation occurs as follows:

1) the excitation by collision with $\mathrm{O}_{2}\left({ }^{1} \Delta \mathrm{g}\right)$ followed by the vibrational relaxation populates all the levels under $V^{\prime \prime}=43$ :

2) dissociation:

$$
\mathrm{O}_{2}\left({ }^{1} \Delta g\right)+\mathrm{I}_{2}\left(X, 0 \leqslant \mathrm{~V}^{\prime \prime} \leqslant 3\right) \rightarrow \mathrm{O}_{2}\left({ }^{3} \Sigma_{\mathrm{g}}^{-}\right)+\mathrm{I}_{2}\left(X, V^{\prime \prime} \leqslant 43\right)
$$

$$
\mathrm{O}_{2}\left({ }^{1} \Delta g\right)+\mathrm{I}_{2}\left(X, 30 \leqslant V^{\prime \prime} \leqslant 43\right) \stackrel{\text { kdiss }}{\longrightarrow} 0_{2}\left({ }^{3} \Sigma_{g}\right)+2 I\left({ }^{2} P_{3 / 2}\right)
$$

Only the levels with $V^{\prime \prime}$ between 30 and 43 have an energy sufficient to lead to the dissociation in a single collision with $\mathrm{O}_{2}\left({ }^{1} \Delta \mathrm{g}\right)$. Another process has been proposed by Nota et a ${ }^{(5)}$. According to this process, the first step of the dissociation is the same as in references ${ }^{1,2,3}$ mechanism. 
The second step is:

$$
0_{2}\left({ }^{1} \Delta g\right)+I_{2}\left(X, V^{\prime \prime} \geqslant 10\right) \rightarrow 0_{2}\left({ }^{3} \Sigma_{g}^{-}\right)+I_{2}\left(A_{2 u}^{\prime}\right)
$$

As $A_{2 u}^{\prime}$ is a non radiative state, it can be the intermediate species of the dissoc process. Finally, the dissociation would occur as follows:

$$
\begin{gathered}
I_{2}\left(A_{2 u}^{\prime}\right)+O_{2}\left({ }^{1} \Delta g\right) \underset{\text { high vibrational levels }}{\rightarrow} 0_{2}\left({ }^{3} \Sigma_{g}^{-}\right)+I\left({ }^{2} P_{3 / 2}\right)+I\left({ }^{2} P_{1 / 2}\right) \\
\text { high }
\end{gathered}
$$

or

$$
\begin{aligned}
& I_{2}\left(A_{2 u}^{\prime}\right)+0_{2}\left({ }^{1} \Delta g\right) \rightarrow 0_{2}\left({ }^{3} \Sigma_{g}\right)+2 I\left({ }^{2} P_{3 / 2}\right) \\
& \text { low vibrational levels }
\end{aligned}
$$

This process requires three collisions with a singlet oxygen molecule. But, in the reaction (4), one of the two iodine atoms is produced in the ${ }^{2} \mathrm{P}_{1 / 2}$ state the energy of which corresponds to the singlet oxygen energy. So, in this case, it is equivalent to a two-step process if the energy consumption is considered. Previous experimental results have shown that the $I_{2}\left(X, V^{\prime \prime} \leqslant 43\right)$ levels and the $I_{2}\left(A_{2 u}^{\prime}\right)$ state are significantly populated ${ }^{(5,6,7)}$. The aim of the present work is to perform absolute measurements of the iodine vibrational level populations along the reaction zone in order to check the existence of the reactions (2) and (3) and to observe their effects.

\section{2 - Experimental}

The laser excites the iodine molecules from the vibrational levels with $5 \leqslant V \leqslant 43$ of the X-state to levels of the B-state. The B-X LIF can be observed (figure 1). The laser linewidth is about $50 \mathrm{MHz}$. This is lower than the $700 \mathrm{MHz}$ of the jodine lines. The excitation spectra are obtained by scanning the laser wavelength in a $30 \mathrm{GHz}$ range. Each scan begins at a different wavelength. The theoretical spectra are calculated by assuming an approximate iodine vibrational population distribution and an estimated rotational temperature. These populations are adjusted by a comparison of the experimental spectra and theoretical spectra, using a non linear least squares fit inversion method described $i n^{2.7 .8}$. The levels $V "$

\begin{tabular}{|c|c|c|c|}
\hline $\begin{array}{c}\text { Total } \\
\text { oxygen pressure (Torr) }\end{array}$ & $\begin{array}{lll}\% & 0 & { }^{1} \Delta\end{array}$ & $\begin{array}{c}\text { Iodine pressure } \\
\text { (Torr) }\end{array}$ & $\begin{array}{c}\mathrm{H}_{2} \mathrm{O} \text { pressure } \\
\text { (Torr) }\end{array}$ \\
\hline 1 & $5-10 \%$ & $4310^{-3}$ & 0 \\
\hline 1 & 0 & $4310^{-3}$ & 0 \\
\hline 0,170 & $5-10 \%$ & $7,3 \quad 10^{-3}$ & 0 and $3010^{-3}$ \\
\hline
\end{tabular}
between 17 and 43 are probed with the LDS 821 dye $(800-850 \mu \mathrm{m})$ and the levels $\mathrm{I}_{2}\left(X, 5 \leqslant \mathrm{~V}^{\prime \prime} \leqslant 25\right)$ are detected with the DCM dye in the $635-680 \mathrm{~nm}$ range. The reaction takes place in a $2 \times 2 \times 17 \mathrm{~cm}^{3}$ movable square glass tube (figure 2 ). The physical parameters are given in the table $I$.

Table I

Experimental conditions used in the laser excitation experiments

\section{3 - Results}

The main results presented here have been obtained at an oxygen pressure of 1 Torr and with a iodine concentration of $1,3810^{15} \mathrm{molecules} / \mathrm{cm}^{3}$. In these conditions, the maximum iodine dissociation rate is about $46 \%$ and is reached $2.10^{-3} \mathrm{~s}$ after the 
iodine injection (figure 3 ). The figure 4 shows the vibrational population distribution in the reaction zone. It is deduced by joining the vibrational population curves obtained with the DCM and the LDS 821 dyes. Its shape does not change along the reaction zone or with water vapor added in the flow. The absolute concentration measurements of the vibrational levels are possible by comparison with the concentration measurements of the lowest vibrational levels at room temperature. The ratio $\left[I_{2}\left(X, 30 \leqslant V^{\prime \prime} \leqslant 43\right)\right] /\left[I_{2}\right]$ is about $3.10^{-4}$, in good agreement with the results of Van Benthem and Davis(1). The figures 5 and 6 show the vibrational levels concentrations versus time obtained respectively with DCM and LDS 821 dyes.

The main new fact is the existence of a concentration depletion for the levels above $V^{\prime \prime}=10$, which occurs simultaneously with the maximum dissociation rate. Now, the $V^{\prime \prime}=11$ level is the first from which the excitation towards $A_{24}^{\prime}$ by collision with the singlet oxygen is exoenergetic. So, this depletion can be the consequence of the reaction (3) which is a step of the dissociation mechanism involving the $A_{2 u}$ state.

\section{4 - Conclusion}

It can be deduced from the figure 3 that the average dissociation speed during the first millisecond is about $5.810^{17}$ molécules $\mathrm{cm}^{-3} \mathrm{~s}^{-1}$. The dissociation speed calculated with the upper values $\left[0_{2}\left({ }^{1} \Delta g\right)\right]=3.210^{15} \mathrm{~cm}^{-3}, k_{\text {diss }}=3.10^{-10} \mathrm{~cm}^{3} \mathrm{~s}^{-1},(4)$ and $\left[\mathrm{I}_{2}^{*}\right]=4.13 .10^{11} \mathrm{~cm}^{-3}$, is about $4.10^{17}$ molecules $\mathrm{cm}^{-3} \mathrm{~s}^{-1}$. So the part of the iodine molecules which are dissociated by collision between $I_{2}\left(X, 30 \leqslant V^{\prime \prime} \leqslant 43\right)$ and $\mathrm{O}_{2}\left({ }^{1} \Delta \mathrm{g}\right)$ does not exceed $70 \%$. Moreover, the depletion of the low vibrational levels population agrees with the dissociation from the $A_{2 u}^{\prime}$ state. In our low singlet oxygen concentration conditions, this last mechanism can be dominant, especially if one consider the vibrational relaxation efficiency and the value $\left[I_{2}\left(X, V^{\prime \prime}=10\right)\right]=410^{12} \mathrm{~cm}^{-3}$. These results show that the two processes are in competition. Their relative importance may change with the singlet oxygen concentration (about $60 \%$ in the COIL) or with the water vapor concentration and it is difficult to identify the dominant process without a more extensive study.

\section{References}

[1] - VAN BENTHEM, M.H., DAVIS, S.J., J. Phys, Chem., 90 (1986), 902.

[2] - CROZET, P., BACIS, R., BOUVIER, A., BOUVIER, A.J., CHURASSY, S. and PIQUE, J.P., J. Physique, C7, 48 (1987), 385-387.

[3] - DAVID, D., JOLY, V., and FAUSSE, A., Proceedings in Physics, 15 (Springer Berlin) (1987), 156-162.

[4] - HEIDNER III, R.F., GARDNER, C.E., SEGAL, G.I., and EL SAYED, T.M., J. of Phys. Chem., 87 (1983), 2348-2360.

[5] - NOTA, M., BOUVIER, A.J., BACIS, R., BOUVIER, A., CROZET, P., CHURASSY, S., and KOFFEND, J.B., J. Chem., Phys., 91(3) (1989), 1938.

[6] - JOLY, V., "Theoretical and experimental study of kinetics mechanisms in the chemical oxygen-jodine laser (COIL)", Thesis published by ONERA, Publication $n^{\circ} 1990-1$.

[7] - BOUVIER, A.J., BACIS, R., BOUVIER, A., CROZET, P., CHURASSY, S., and NOTA, M., in Proceedings of the 7th Int. Symp. on Gas Flow and Chemical Lasers, $D$. Schuöcker, ed. SPIE, 1031, (1988), 294-300. 
[8] - CERNY, D., BACIS, R., BOUVIER, A.J., POULA, S.,TOUPOUZKANIAN, A., and VERGES, J., submitted to J.Q.S.R.T.

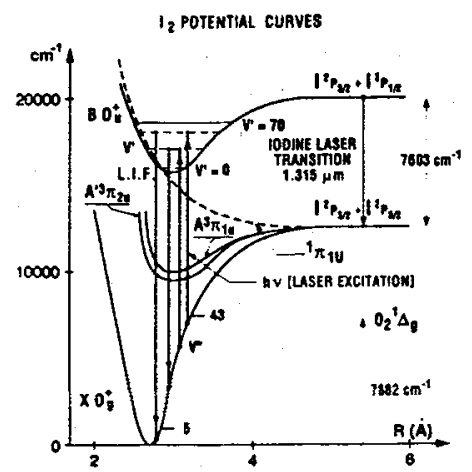

Fig. 1 - Transitions involved in the laser excitation experiments.

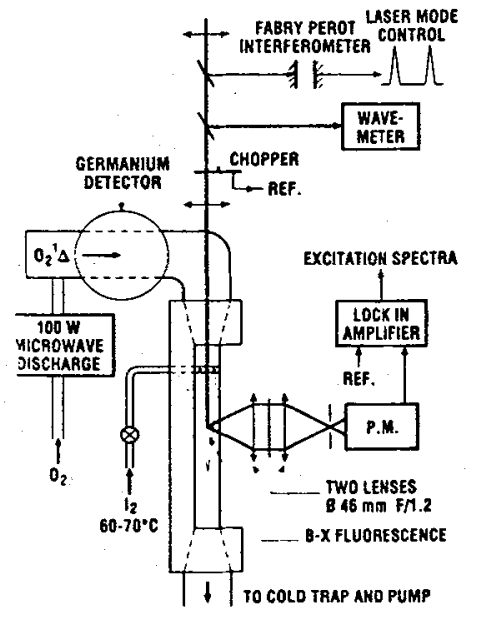

Fig. 2 - Experimental set-up.

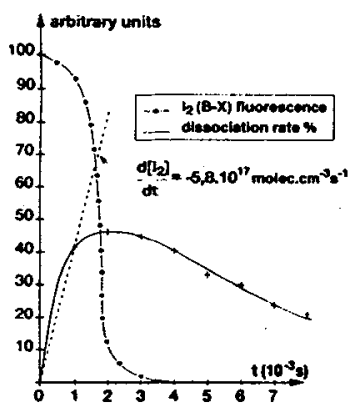

Fig. $3-I_{2}(B \rightarrow X)$ fluorescence and dissociation rate versus time.

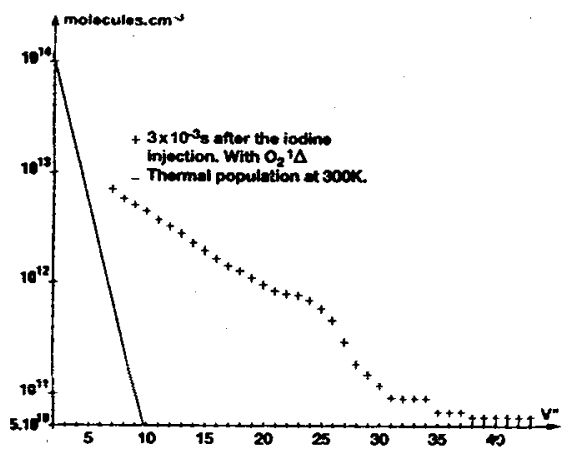

Fig. 4 - Vibrational population distribution.

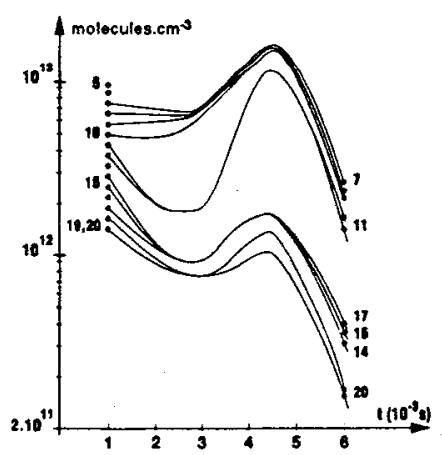

Fig. 5 - Iodine vibrational population $I_{2}\left(X, 5 \leq V^{\prime \prime} \leq 20\right)$ versus time. DCM dye.

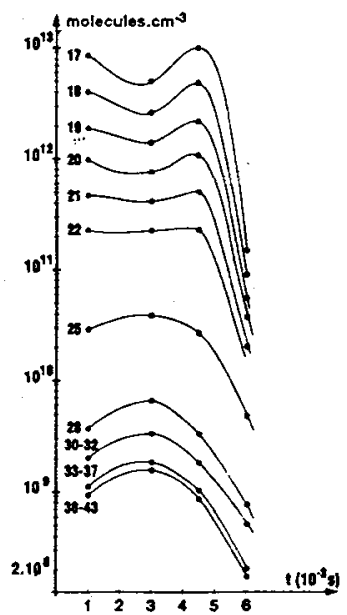

Fig. 6 - Iodine vibrational population $I_{2}\left(X, 17 \leq V^{\prime \prime} \leq 43\right)$ versus time. LDS 821 dye. 